GEOFIZIKA VOL. $37 \quad 2020$

DOI: https://doi.org/10.15233/gfz.2020.37.2

Original scientific paper

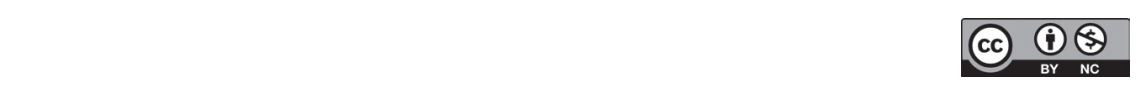

\title{
Flood hazard assessment of a flood-prone intensively urbanized area - A case study from Samsun Province, Turkey
}

\author{
Neslihan Beden ${ }^{1}$ and Aslı Ülke Keskin ${ }^{2}$ \\ ${ }^{1}$ Samsun University, Kavak Vocational School, Construction Department, Samsun, Turkey \\ ${ }^{2}$ Ondokuz Mayıs University, Engineering Faculty, Civil Engineering Department, Samsun, Turkey
}

Received 4 January 2020, in final form 13 March 2020

\begin{abstract}
Flooding is one of the most catastrophic events among the wide spectrum of natural disasters that impact human communities. The identification of floodprone areas and the probability of occurrence, or estimated return period, of flood events are fundamental to proper planning for flood management and minimization of the social and economic costs of flood damage. In this study, 1D/2D coupled flood models of the Mert River, which flows into the Black Sea at Samsun in north-central Turkey, were developed. Based on the flood modeling results, flood extent, flood depth and flood hazard maps for the river were produced and they showed that the study area is particularly flood prone, as evidenced by catastrophic flooding in 2012. Specifically, the estimated 100, 500 and 1000-year peak discharges would affect 184 ha, 262 ha and 304 ha, respectively, of the 1,200 ha study area. Hazard ratings for the areas expected to be affected are shown in the flood hazard maps generated. The results of this research can be used by local government agencies in Samsun for the development of policies, strategies and actions that would help minimize the social and economic impacts of flooding, especially adjacent to the downstream sections where there is intensive development on the flood plain.
\end{abstract}

Keywords: flood modeling, flood mapping, MIKE FLOOD, Samsun, Turkey

\section{Introduction}

Flooding is considered one of the most devastating natural hazards affecting human communities. If floods occur in urban environments, they affect most aspects of human life, including social and economic activity, with larger flood events reflected in higher costs (Bellos and Tsakiris, 2015). The modeling of potential urban flooding scenarios is an important process for many reasons, with the increasing need for anticipating and managing flood events being the 
most important. Flood management systems are based primarily upon the modeling of floods. There are many models currently available for one-dimensional (1D), two-dimensional (2D) and one/two dimensional coupled (1D/2D) hydrodynamic calculations. These models are suitable for simulating different return period floods (Quiroga et al., 2016). The use of 1D, 2D or 1D/2D modeling depends on the required outcome and sufficiency of the data. Comparisons of $1 \mathrm{D}$ and $2 \mathrm{D}$ modeling have been made by many researchers (Horritt and Bates, 2002; Alho and Aaltonen, 2008; Leedal et al., 2010; Vozinaki et al., 2017). Gul et al. (2010) developed hydrologic and hydraulic models for the Bostanli Basin in Izmir, Turkey with 1D HEC-RAS. In a study particularly relevant to the current study, Ahmed (2010) used MIKE 11 modeling for basin management, river network and water control structures on the Rideau River in Canada. Masood and Takeuchi (2012), who evaluated the flood-proneness of areas of the Dhaka city in Bangladesh, produced a flood hazard map with 1D modeling, based on terrain and hydrological models. In an Indian study, Timbadiya et al. (2014) did 1D modeling with MIKE 11 and HEC-RAS to generate predictive stage hydrographs of the Lower Tapi River under unsteady conditions. In a study of potential flooding events, ShahiriParsa et al. (2016) used HEC-RAS 1D and CCHE2D modeling to estimate the extent of inundation and the water depth in the Sungai Maka, Malaysia. Furthermore, Vojtek and Vojteková (2016) performed HEC-RAS 1D modeling to estimate the vulnerability of the Vycoma River in Slovakia to flooding, based on discharge volume and water depth, and subsequently prepared flood hazard maps in low, medium and high risk categories.

Even though it is simple to use and practical, 1D flow modeling only performs a one-directional calculation, which results in intermittent blanks between crosssections. Thus, 1D modeling is unsuitable for application to complicated flow systems and complex terrains (Huthoff et al., 2015). One dimensional modeling is suitable for steady flow analysis and is most coherent when combined with Geographic Information Systems (GIS) when pre-processing and post-processing tasks are performed (De Roo et al., 2000; Maidment and Djokic, 2000; Zerger and Wealands, 2004; Cesur 2007). Recent studies have shown that 2D flood models can incorporate the topographic and geometric properties of terrain in their calculations (Cook and Merwade, 2009). Through 2D modeling, the terrain can be represented at high resolution by free surface flows and flexible mesh systems and flood extent maps can show the inundation area continuously across the modelled area. Although able to simulate flood inundation at different time intervals, 2D hydraulic models need more data to describe complex, unsteady flows (Bates and De Roo, 2000; Horritt and Bates, 2001). Therefore, the most appropriate modeling system is generally determined by considering the characteristics of the area to be modeled, available resources and data.

The situation in which water overflows a river's banks is a $2 \mathrm{D}$ event and that means 2D modeling is more appropriate. Mignot et al. (2006) developed 2D shallow-water equations for flood modeling and management in an intensely urban- 
ized area. In a similar study, Carrivick (2006) used SOBEK 2D software to simulate a catastrophic flood event in Iceland. In that study, 2D models provided a more realistic understanding of an extreme flood event. Haltas et al. (2016) used the 1D HEC-RAS modeling system for modeling dam failure and flood routeing and obtained output hydrographs for various dam failure scenarios. The same authors then used these hydrographs as input data to FLO-2D for the numerical modeling of the flood wave propagation downstream of the dam. In addition, Komi et al. (2017) used the 2D hydrodynamic modeling system LIS-FLOOD to estimate the extent of the floodplain of the Oti River basin in West Africa.

The objective of flood modeling and risk analysis is to protect people and property against flooding. The increase in damage from social and economic costs of natural disasters is directly related to both the number of people living and working in flood prone areas and the steady increase in the number of 'at risk' assets. Hence, land-use planning authorities should effectively manage the establishment and development of settlements in flood-prone areas to prevent further increases in the number of vulnerable assets (Petrow et al., 2006).

Flooding is not a problem that can be completely eliminated. It is therefore necessary to take preventive measures against floods, especially in urban areas, both in the downstream and upstream sections of rivers. Globally, there is increasing action to predict floods, manage the impacts, and reduce the associated damage. Reducing the damage caused by floods requires different strategies in different areas. For that reason, the objectives and measures employed in flood risk management should be diverse and regionalized. Optimizing flood risk management should not be the only purpose of flood modeling; it should also optimize the potential for performance of activities like the restoration of riverine ecology (Hooijer et al., 2004).

The nature of flood hazard is usually defined by causality, in other words, the probability and magnitude of the flood event. In addition, flooding implies the risk of social and economic costs to the affected areas (Merz et al., 2007). Flood risk is a function of flood hazard and vulnerability. Studies on preparing flood hazard maps have been carried out from the past and continue to be done. Their preparation requires a digital elevation model, cross-sections along the river or channel, and projected flood peaks for different return periods.

Rapid and uncoordinated urbanization, inadequate infrastructure systems and changes in precipitation characteristics attributable to climate change have created more flood prone areas worldwide (Willems et al., 2012). The impacts of floods can manifest as loss of life, injuries, psychological trauma and social dislocation, as well as damage to public infrastructure and private property, all of which have short and long term economic consequences.

In order to reduce the social and economic costs of flooding in Turkey, the Ministry of Agriculture and Forestry General Directorate of Water Management (TOB) is coordinating the production of a Flood Management Plan for each river 
basin. Flood management plans for all river basins in Turkey will be completed by the end of 2021. The frequency and intensity of flooding is expected to increase because of climate change and comprehensive management planning across Turkey could be expected to reduce the social and economic costs of flooding events, if regional governments and local councils strictly implement and police the plans.

In this study, the Mert River, which flows into the Black Sea in the north of Turkey, was the designated study area. In the past, especially 2012, flooding has caused loss of lives, major damage to public and private property, and social disruption. Therefore, the aims of this study were to conduct flood modeling of the downstream areas adjacent to the Mert River which would be expected to ... flood in 100-year (Q100), 500-year (Q500) and 1000-year (Q1000) scenarios, to describe the flood risks, and to generate flood maps. These efforts were collectively designed to assist local, regional and national government to better plan for flooding events and hence reduce their social and economic impacts.

\section{Study area}

The city of Samsun is in Samsun Province which is located in the central Black Sea region of northern Turkey and has a total area of $9,083 \mathrm{~km}^{2}$. The Mert River flows into the Black Sea near the city center. The study area, the most downstream $7 \mathrm{~km}$ section of the river, is located between $40^{\circ} 50^{\prime}$ and $41^{\circ} 51^{\prime} \mathrm{N}$ and $37^{\circ} 08^{\prime}$ and $34^{\circ} 25^{\prime} \mathrm{E}$. The typical Black Sea climate is experienced in the study area. Based on data from the Samsun Meteorological Observations Station, the average annual precipitation in Samsun city is $674.8 \mathrm{~mm}$, with the highest and lowest precipitations in November (mean $70.8 \mathrm{~mm}$ ) and August (mean $29.4 \mathrm{~mm}$ ), respectively (Turkish State Meteorological Service (MGM), 2018). The Mert River basin is located between the Kizilirmak and Yesilirmak River basins, which are two of Turkey's largest watersheds. The Mert River rises at 1,319 m in the mountains to the south-west of Samsun and follows a $73 \mathrm{~km}$ course from the southwest to the northeast down the slopes, across the lowlands and into the Black Sea. In this study, the most downstream 1,200 ha area of the river basin, from the sea to $7 \mathrm{~km}$ upstream, was selected for flood modeling, because that area is both the most vulnerable to flooding and the most intensively developed. In Fig. 1, the location of the Mert River system is shown (General Directorate of State Hydraulic Works (DSI), 2013).

The most downstream section $(10 \% / 7 \mathrm{~km})$ of the Mert River flows through a major commercial, industrial and urban area of Samsun city that also features social and cultural facilities. There are five main road bridges, including one on a major trans-city, coastal road; a tramway bridge; and a pedestrian bridge, crossing the river in the study area. The most downstream four bridges are located near the sea and facilitate transport along the Black Sea, although there is a city bypass. The locations of the bridges (C1-C7) are shown in Fig. 2 and their features (obtained from authors' surveys) are shown in Tab. 1. 


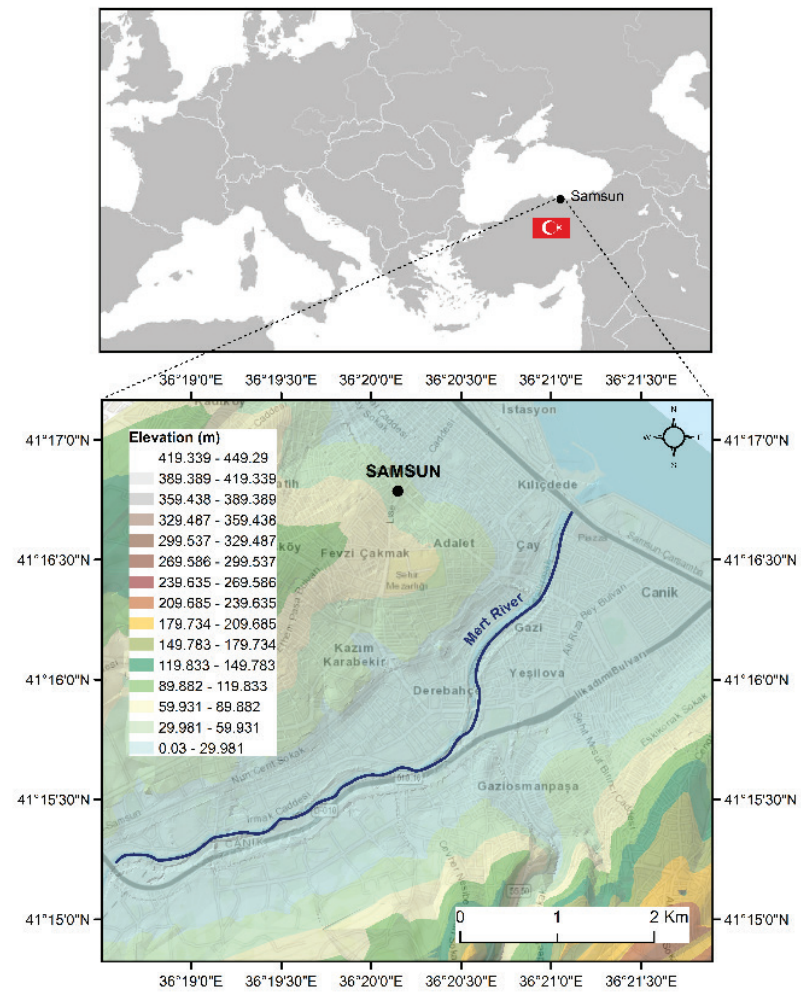

Figure 1. Location of the Mert River, Samsun Province, Turkey.

A major flood disaster was experienced in the study area on 4 July, 2012. Four hundred and fifty one houses, 19,140 flats, 1,326 commercial and industrial premises, 6 mosques, 1 school, 1 warehouse, 1 bridge, 153 storages (in industrial area)

Table 1. Locations of the bridges on the Mert River, Samsun, Turkey.

\begin{tabular}{lllccc}
\hline Km & Latitude (N) & Longitude (E) & Notation & $\begin{array}{c}\text { Top elevation } \\
\text { (from the } \\
\text { thalweg) }(\mathrm{m})\end{array}$ & $\begin{array}{c}\text { Deck } \\
\text { thickness } \\
(\mathrm{m})\end{array}$ \\
\hline $0+260$ & $41^{\circ} 16^{\prime} 43.96^{\prime \prime}$ & $36^{\circ} 21^{\prime} 08.74^{\prime \prime}$ & $\mathrm{C} 1$ & 4.05 & 1.70 \\
$0+300$ & $41^{\circ} 16^{\prime} 43.91^{\prime \prime}$ & $36^{\circ} 21^{\prime} 07.19^{\prime \prime}$ & $\mathrm{C} 2$ & 3.50 & 1.00 \\
$0+350$ & $41^{\circ} 16^{\prime} 43.19^{\prime \prime}$ & $36^{\circ} 21^{\prime} 06.32^{\prime \prime}$ & $\mathrm{C} 3$ & 3.80 & 0.80 \\
$0+400$ & $41^{\circ} 16^{\prime} 41.75^{\prime \prime}$ & $36^{\circ} 21^{\prime} 04.32^{\prime \prime}$ & $\mathrm{C} 4$ & 4.00 & 0.90 \\
$1+000$ & $41^{\circ} 16^{\prime} 22.84^{\prime \prime}$ & $36^{\circ} 20^{\prime} 55.67^{\prime \prime}$ & $\mathrm{C} 5$ & 7.00 & 1.60 \\
$1+800$ & $41^{\circ} 16^{\prime} 03.83^{\prime \prime}$ & $36^{\circ} 20^{\prime} 34.11^{\prime \prime}$ & $\mathrm{C} 6$ & 5.90 & 1.50 \\
$2+150$ & $41^{\circ} 15^{\prime} 52.53^{\prime \prime}$ & $36^{\circ} 20^{\prime} 33.14^{\prime \prime}$ & $\mathrm{C} 7$ & 14.70 & 1.20 \\
\hline
\end{tabular}




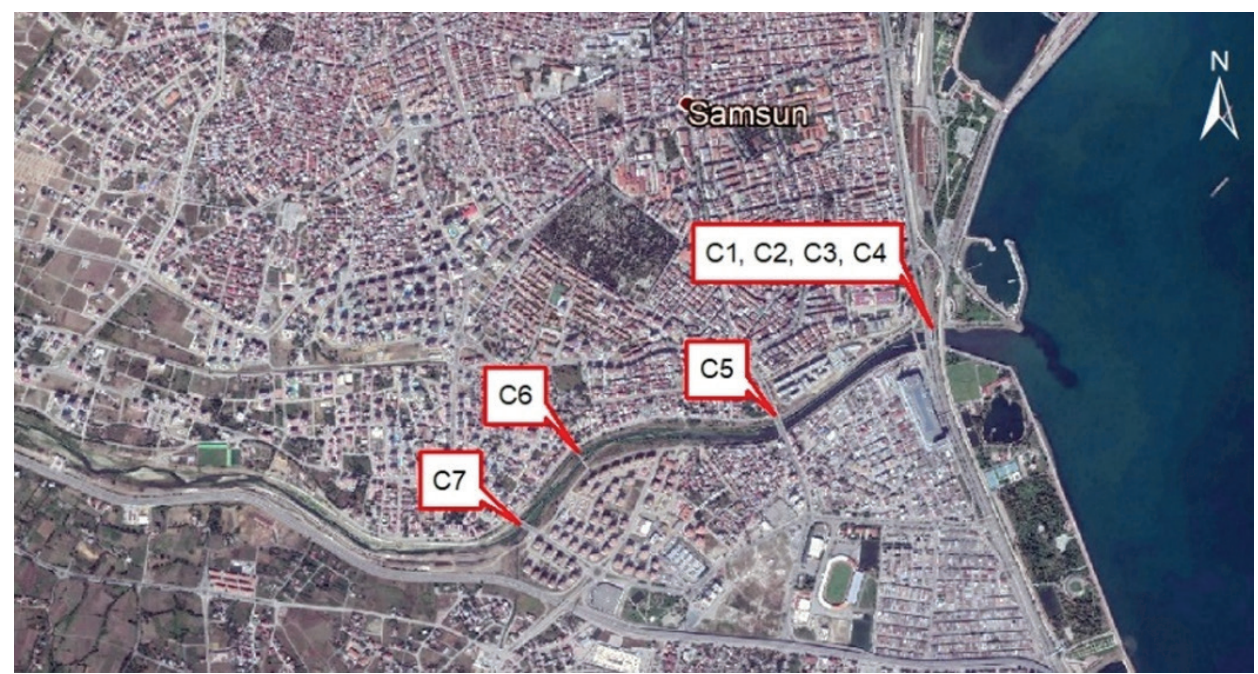

Figure 2. Bridge locations on the Mert River, Samsun Province, Turkey.
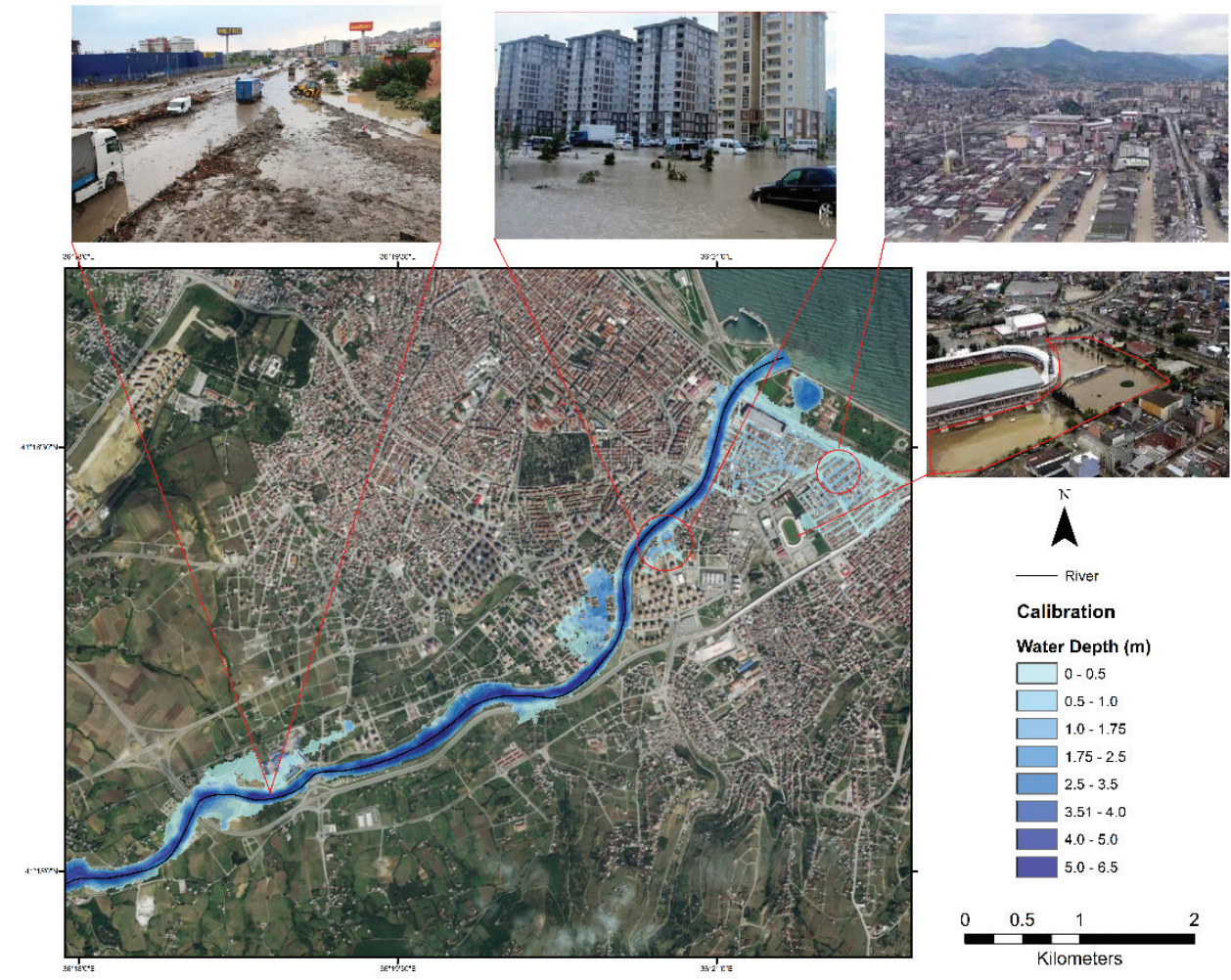

- River

Calibration

Water Depth $(m)$
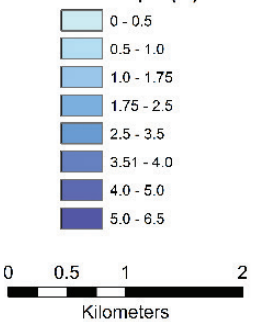

Figure 3. Flooding of the Mert River in Samsun, Turkey in 2012. 
and 1 sports hall were affected by the flood (DSI, 2013). The maximum discharge rate of the river measured by the Turkish General Directorate for State Hydraulic Works (Samsun Office) nearby the bridge C1 was $570 \mathrm{~m}^{3} / \mathrm{s}$. The MIKE 11 and MIKE 21 models used in this study were calibrated with the measurements and photographs of the event. The inundated areas and water depths for the 2012 flow rate were compared with the real event and results found quite similar (Fig. 3). Nevertheless, the models could not be validated there was not enough data for the study area.

\section{Flood scenarios}

The prediction of flood damage is a major task for engineers and authorities responsible for floodplain management (Pearson and Davies, 1997). One of the most important steps in flood management is flood modeling. Firstly, it is necessary to calculate the discharge of the stream or river for different return periods in the flood model.

The Corak stream gauge station (SGS) is in the study area on the Mert River and the available data covers the period of 2007-2015. However, for statistical purposes there were an insufficient number of flow data to calculate flood peak discharges (Bayazit, 1981). Therefore, the Mockus synthetic unit hydrograph method (Mockus, 1965) was used in the calculation of the flood discharges.

\subsection{Mockus synthetic unit hydrograph method}

The characteristics of the meteorological stations operated by the Turkish State Meteorological Service that were used in the Mert River basin analysis are given in Tab. 2.

The log-Pearson, type-3 distribution was chosen as the best fitting frequency distribution for these stations maximum 24-hour rainfall rates (KolmogorovSmirnov test) to calculate the annual 24-hour precipitation amount for different rotation periods. It was actually the best fitting distribution for all three stations. For the Mert River basin, the recurrence values of daily maximum precipitation were calculated according to Thiessen polygon ratios. The corrected maximized rainfall magnitudes for the basin for different return periods were determined directly by multiplying the calculated daily precipitations of the Samsun station

Table 2. Meteorological stations located in the Mert River study area.

\begin{tabular}{cccccc}
\hline $\begin{array}{c}\text { Station } \\
\text { number }\end{array}$ & Station & $\begin{array}{c}\text { Latitude } \\
(\mathrm{N})\end{array}$ & $\begin{array}{c}\text { Longitude } \\
(\mathrm{E})\end{array}$ & Period & $\begin{array}{c}\text { Thiessen rates } \\
(\%)\end{array}$ \\
\hline 14017 & Mazlumoglu & $40.92^{\circ}$ & $36.02^{\circ}$ & $1959-2012$ & 50.92 \\
17030 & Samsun & $41.34^{\circ}$ & $36.25^{\circ}$ & $1960-2018$ & 36.60 \\
1125 & Cakiralan & $41.17^{\circ}$ & $35.76^{\circ}$ & $1969-2018$ & 12.48 \\
\hline
\end{tabular}


N. BEDEN AND A. ÜLKE KESKIN: FLOOD HAZARD ASSESSMENT OF A FLOOD-PRONE ...

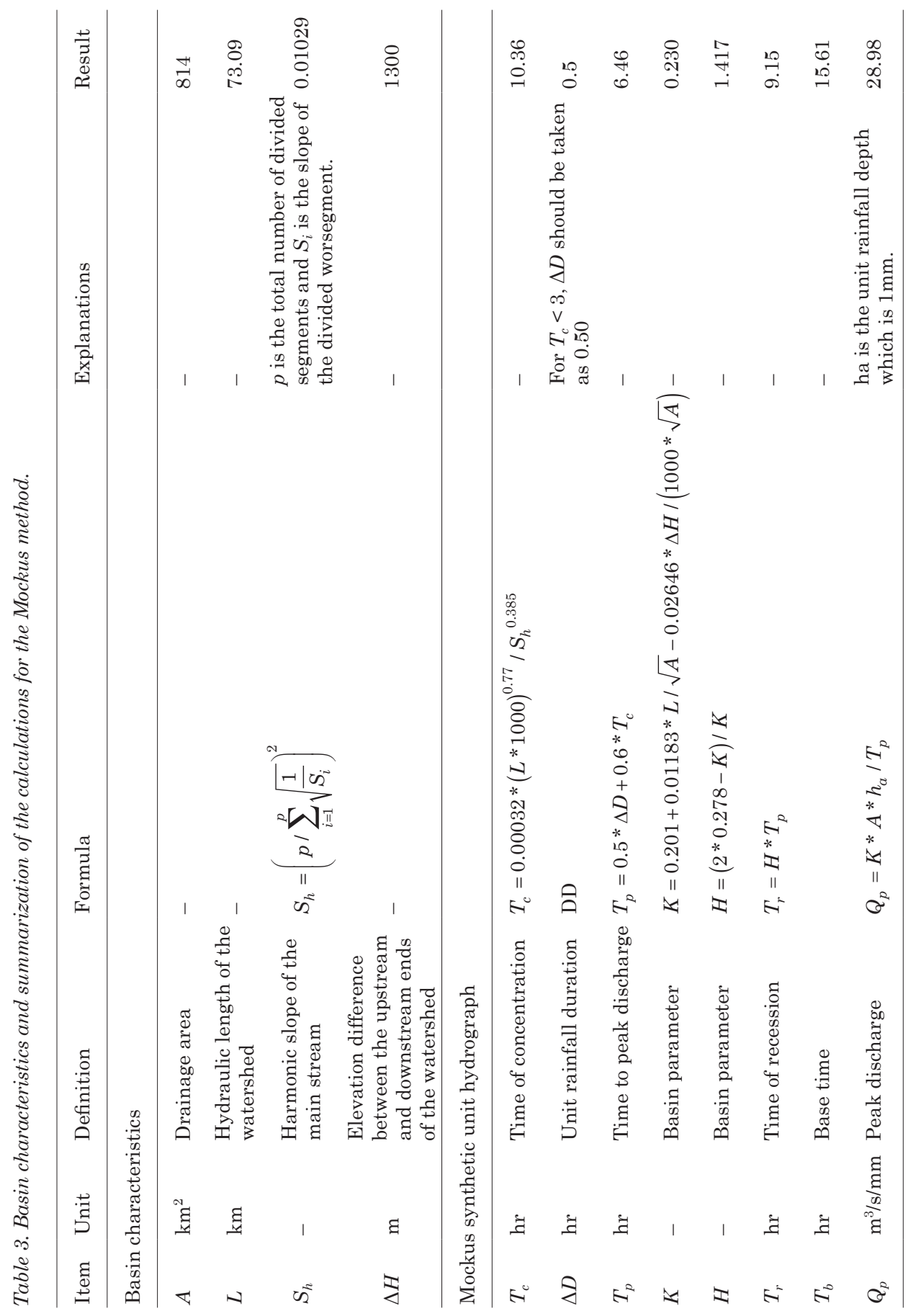


Table 4. Estimated peak discharges for the Mert Basin $\left(\mathrm{m}^{3} / \mathrm{s}\right)$.

\begin{tabular}{lcccccccc}
\hline Years & 2 & 5 & 10 & 25 & 50 & 100 & 500 & 1000 \\
\hline Dicharge $\left(\mathrm{m}^{3} / \mathrm{s}\right)$ & 344.3 & 517.5 & 659.9 & 883.4 & 1088.8 & 1334.4 & 1801.15 & 2002.15 \\
\hline
\end{tabular}

by the pluviograph coefficients for the station, the areal distribution coefficients of rainfall for the basin, and the maximisation factor, 1.13, as advised by the DSI (Ozdemir, 1978).

The applicable parameters in the determination of the Mockus synthetic unit hydrograph were the drainage area, hydraulic length of the basin, distance from the basin outlet to a point on the main stream nearest to the centroid of the drainage area, and the harmonic slope of the main stream (Mockus, 1965). These values were measured by using a 1/25,000 scale digital topography map of the basin. The basin characteristics and the details of the Mockus method is given in Tab. 3. The Mockus method is a $0.5 \mathrm{hr}$ triangular hydrograph and in this study a calculations peak discharge of $28.98 \mathrm{~m}^{3} / \mathrm{hr} / \mathrm{mm}$, a time to peak discharge of $6.46 \mathrm{hr}$ and a base time of $15.61 \mathrm{hr}$ were calculated. The critical precipitation period for this basin, taken from the map showing regional critical precipitation times for the whole country, was 18 hours. Precipitation amounts during this critical precipitation period were divided into unit hydrographic blocks by using the A type precipitation distribution curve for the Mockus method (Ozdemir, 1978; Yalcin, 2018). Peak discharges for different return period floods for the Mert Basin $\left(\mathrm{m}^{3} / \mathrm{s}\right)$ are given in Tab. 4. Flood hydrographs of the Mert River are given in Fig. 4.

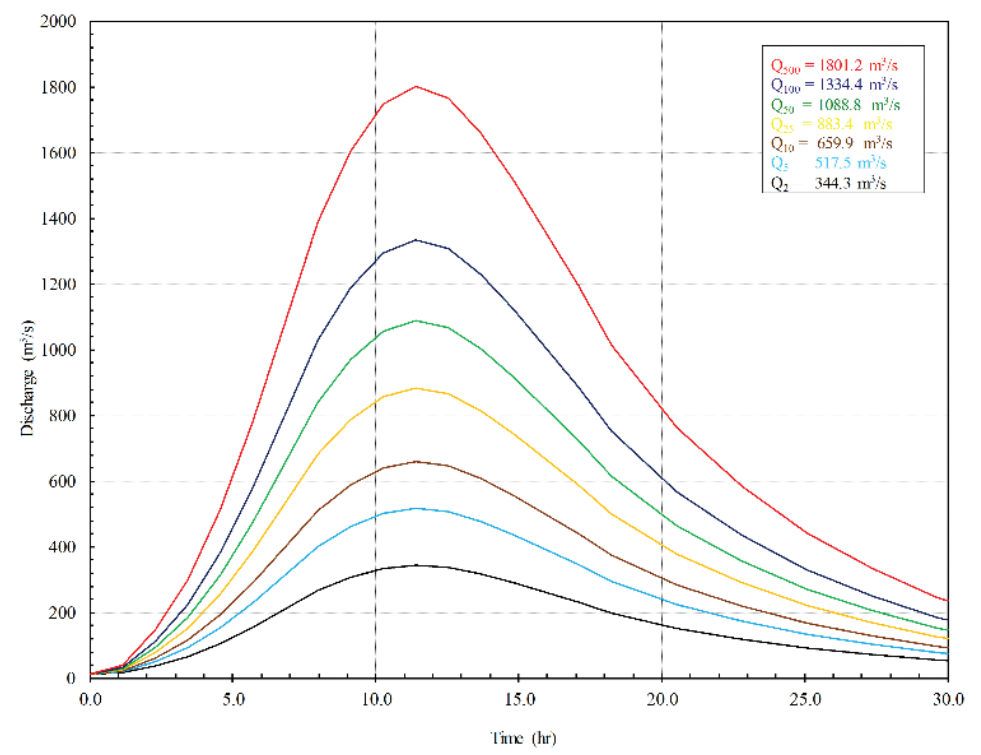

Figure 4. Flood hydrographs of the Mert River. 


\section{Flood modeling}

In this study, MIKE 11 (1D) software was used to model the Mert River bed. However, MIKE 21 (2D) software and combined 1D-2D MIKE FLOOD software were used to determine the extent of the flooded area. To create the river crosssections, bathymetric mapping was used; 1:1,000 scale maps were used as the base maps and field measurements of levees, banks and hydraulic structures were incorporated in the map at $50 \mathrm{~cm}$ sensitivity.

\subsection{D Hydraulic-hydrodynamic model}

The MIKE 11 HD solves the Saint Venant Equations in one-dimensional environment. In MIKE 11, engineering structures can be defined, e.g., weirs, culverts and piers, and then river flows over, through or around these structures can be calculated. Equations 3 and 4 are the equations for continuity and momentum, respectively, of flow (Danish Hydraulic Institute (DHI), 2016a).

$$
\begin{gathered}
\left(\frac{d q}{d x}\right)+\left(\frac{d A_{f l}}{d t}\right)=q_{i n} \\
\left(\frac{d q}{d x}\right)+\frac{\left(\frac{\alpha q^{2}}{d A_{f l}}\right)}{d x}+g A_{f l} \frac{d h}{d x}+\left(\frac{g q|q|}{C^{2} A_{f l} R}\right)=0
\end{gathered}
$$

In these equations, $A$ is the flow area $\left(\mathrm{m}^{2}\right), q$ is the lateral flow $\left(\mathrm{m}^{2} / \mathrm{s}\right), h$ is the water depth $(\mathrm{m}), C$ is the Chezy roughness coefficient $\left(\mathrm{m}^{1 / 2} / \mathrm{s}\right), \alpha$ is the mo-

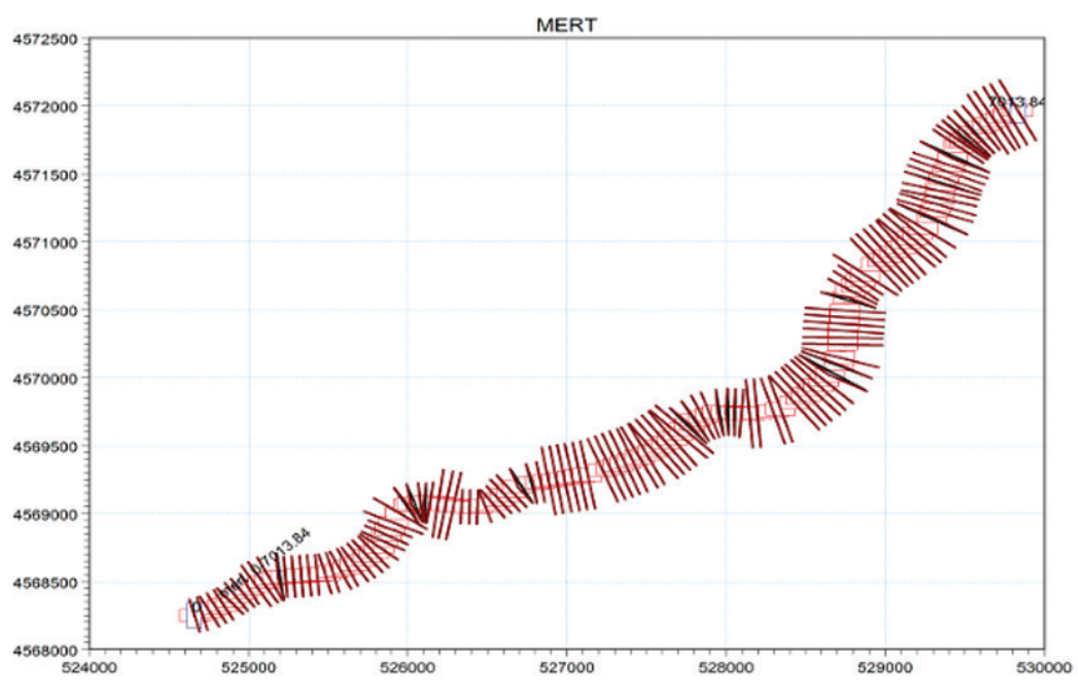

Figure 5. Cross-sections along the most seaward $7 \mathrm{~km}$ of the Mert River in Samsun, Turkey. 
mentum distribution coefficient, $x$ is the chainage and $g$ is the acceleration due to gravity $\left(\mathrm{m} / \mathrm{s}^{2}\right)$. The hydraulic model was primarily produced with a digital elevation model (DEM) generated by digitizing the 1:1,000 sensitivity topographic maps. The MIKE 11 calculated the water depths in the cross-sections with the help of elevation values obtained from the DEM. One hundred and thirty two cross-sections were created at 20-, 30- and 50-m intervals along the subject $7 \mathrm{~km}$ of the river course (Fig. 5), while simultaneously incorporating the effects of terrain topography and engineering structures on the river.

\subsection{D Hydrodynamic model}

The MIKE 21 Flow Model FM, which was developed for free surface flow applications, originated from the flexible mesh approach. The hydrodynamic module (HD) in the model simulates unsteady flow by considering bathymetry, external forces and density variations. The MIKE $21 \mathrm{HD}$ modeling system is based on the solution of the depth-averaged two-dimensional Saint Venant equations (DHI, 2016b):

$$
\begin{gathered}
\frac{\partial s}{\partial t}+\frac{\partial}{\partial x} U h+\frac{\partial}{\partial x} V h=F_{s} \\
\frac{\partial s}{\partial t}+U \frac{\partial}{\partial x}+V \frac{\partial}{\partial y}+g \partial_{x} s+\frac{g}{C^{2} d} U \sqrt{U^{2}+V^{2}}+\frac{\partial}{\partial x}\left(K_{x x} \frac{\partial U}{\partial x}\right)+\frac{\partial}{\partial y}\left(K_{y y} \frac{\partial U}{\partial y}\right)=F_{s} \\
\frac{\partial s}{\partial t}+U \frac{\partial V}{\partial x}+V \frac{\partial V}{\partial y}+\frac{\partial s}{\partial x}+\frac{g}{C^{2} d} V \sqrt{U^{2}+V^{2}}+\frac{\partial}{\partial x}\left(K_{x x} \frac{\partial U}{\partial x}\right)+\frac{\partial}{\partial y}\left(K_{y y} \frac{\partial U}{\partial y}\right)=F_{s} V_{s}
\end{gathered}
$$

In Eqs. (5)-(7), where $s$ is the height, $h$ is the total water depth, $U$ and $V$ are the notations for the depth-averaged Cartesian velocity components, $C$ is the Chezy component, $K_{x x}$ and $K_{y y}$ are the eddy viscosities, $F$ is the source term, and $V_{s}$ and $U_{s}$ are the velocity components at the source (DHI, 2016b).

The use of the 'flexible mesh' approach allows the realistic simulation of terrain. The most important advantage is that the mesh size can be produced frequently in parts where precise calculation is required, and less intensively increased in size in other parts (Fig. 6). Moreover, the duration of the simulation and the stability of the model can be adjusted optimally. A $5 \mathrm{~m}^{2}$ mesh interval was selected for places close to the river where structures were located at frequent intervals. A small mesh size was necessary in these areas to best represent the intensive development areas on the river banks and near the river. A larger mesh size could be used for less developed areas away from the river and its banks, with a maximum unit size of $50 \mathrm{~m}^{2}$ employed in this study. A sample bathymetry map produced from a digital elevation model with element mesh is shown in Fig. 6, with buildings shown as polygons. 


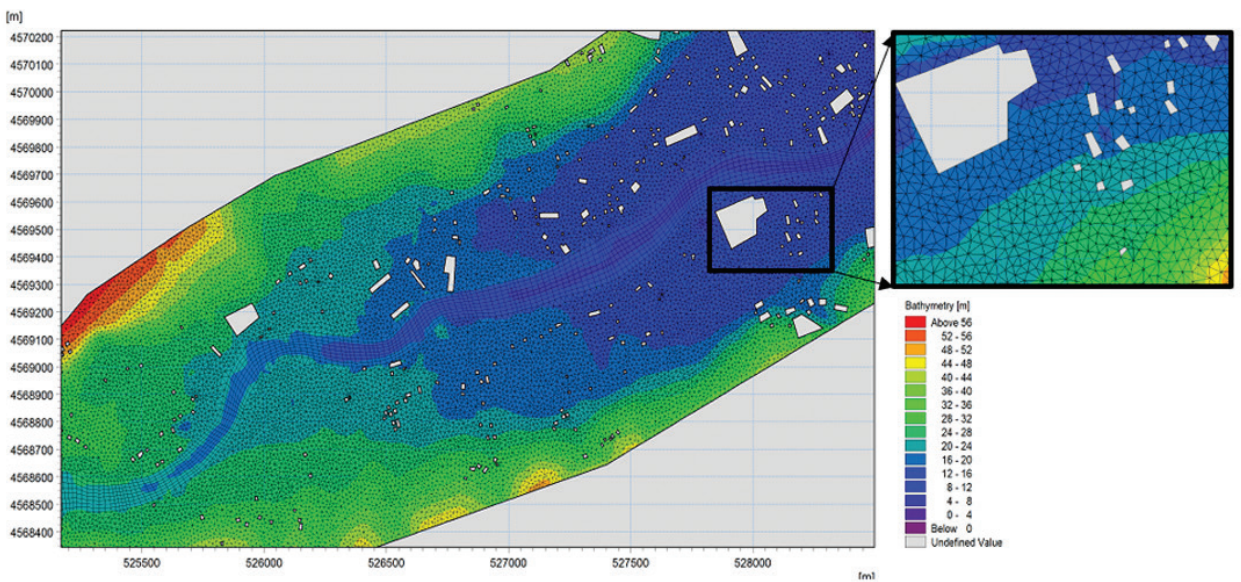

Figure 6. Bathymetry of the study area produced with element mesh.

\subsection{D/2D Hydrodynamic model}

MIKE FLOOD is a one-dimensional/two-dimensional coupled modeling system (1D/2D) which combines the MIKE 11 and MIKE 21 in a single environment. Lateral links were used to connect MIKE 11 and MIKE 21 in MIKE FLOOD environment (DHI, 2016c).

\subsection{Model parameters}

\subsubsection{Friction parameters}

Manning " $n$ " was used as the friction parameter. The Manning roughness coefficient for a particular river is based on field observations, calculations and experimental tables developed by Cowan (1956). In this study, a series of measurements designed to facilitate the determination of Manning roughness coefficients were taken at 6 representative locations along the river's course. Manning roughness coefficients for the six locations are given in Tab. 5. While determining the Manning value for the areas outside the river bed, 1:1,000 current maps which obtained local administrations were utilized. These maps contained details such as roads, buildings and streets. The roughness values corresponding to these details were determined by coefficients based on the type of surface. The roughness values were 0.03 for clean and flat lands in natural beds, 0.030-0.035 (based on plant density), 0.022 for concrete walls, 0.013 for asphalt surfacing, 0.016 for rough asphalt, and 0.040 for gravel and coarse rocks (Chow, 1959; Chaudhry, 2008). In this study, the Manning roughness coefficients ranged between 0.027 and 0.052 . These values are assigned manually with the "mesh editor" of the MIKE $21 \mathrm{FM}$ for the 2D flow area. 
Table 5. Manning roughness coefficients for 6 locations along the Mert River in Samsun, Turkey.

\begin{tabular}{cccc}
\hline $\mathrm{Km}$ & Latitude $(\mathrm{N})$ & Longitude $(\mathrm{E})$ & $n$ \\
\hline $0+000-1+500$ & $41^{\circ} 16^{\prime} 46.16^{\prime \prime}$ & $36^{\circ} 21^{\prime} 12.47^{\prime \prime}$ & 0.027 \\
$1+500-2+500$ & $41^{\circ} 16^{\prime} 15.23^{\prime \prime}$ & $36^{\circ} 20^{\prime} 43.12^{\prime \prime}$ & 0.047 \\
$2+500-3+000$ & $41^{\circ} 15^{\prime} 37.08^{\prime \prime}$ & $36^{\circ} 20^{\prime} 12.15^{\prime \prime}$ & 0.044 \\
$3+000-4+500$ & $41^{\circ} 15^{\prime} 20.15^{\prime \prime}$ & $36^{\circ} 19^{\prime} 12.63^{\prime \prime}$ & 0.051 \\
$4+500-6+500$ & $41^{\circ} 15^{\prime} 05.98^{\prime \prime}$ & $36^{\circ} 18^{\prime} 27.56^{\prime \prime}$ & 0.046 \\
$6+500-7+500$ & $41^{\circ} 14^{\prime} 47.36^{\prime \prime}$ & $36^{\circ} 17^{\prime} 37.41^{\prime \prime}$ & 0.052 \\
\hline
\end{tabular}

\subsubsection{Time and distance parameters}

\section{MIKE 11 maximum $d x$ and $d t$}

Distance $(d x)$ and time $(d t)$ and their parameters are mainly related to stability. These values must be specified independently for each event. To ensure stability, the role of these parameters in meeting the Courant condition is considered (DHI, 2016a). In the MIKE 11 phase, the Mert River $d x$ and $d t$ were determined to be $100 \mathrm{~m}$ and 1 second, respectively.

\section{MIKE 21 time, distance and Courant condition parameters}

In cases where finite difference equations are used for problem solving, the Courant number should be used to obtain model stability (Courant et al., 1928). To achieve model stability, the Courant number must be less than or equal to 1 . The performance of a stable simulation of the shallow water equation also requires data on time, distance and Courant state (CFL) in the MIKE 21 environment. Operator experience and trials are important in the selection of these values (DHI, 2016b). The critical CFL number for the Mert River at the MIKE 21 stage was determined as $<0.9$.

\section{Hydrodynamic parameters}

In flood simulation, the "High Order Fully Dynamic" wave approach is preferred. It is employed as a stability improvement factor, especially in simulations such as flooding where the mass inertia of water is important on a time and distance basis (DHI, 2016b). During the Mert River flood simulation phase, this approach was chosen.

The default values of the hydrodynamic parameters are used as they are, except for the " $\delta$ " value. In flood simulation studies, the default value $\delta$ is increased from " 0.5 " to " 0.80 " because the coefficient $\delta$ refers to the time-centered gravitational acceleration in the momentum equation and is a stability factor (DHI, 2016b). 


\subsection{Flood hazard rating}

In this study, the hazard rating definition adopted was based primarily on the direct risks to people exposed to flooding, and the hazard rating formula is provided in Eq. (8) (Defra, 2006).

$$
H R=d(v+n)+D F
$$

where, $H R$ is the hazard rating, $d$ is flood depth $(\mathrm{m}), v$ is flow velocity $(\mathrm{m} / \mathrm{s}), D F$ is the debris factor and $n$ is a constant (0.5).

Table 6 suggests debris factors for different depths, velocities and the dominant land use, and a scheme for categorizing the level of flood hazard is provided in Tab. 7 (Defra 2006).

In the present study, a debris factor of "0-1" for was selected for the urbanized areas adjacent to the Mert River, based on Tab. 6. In addition, the hazard ratings were calculated in the ArcGIS environment with the Spatial AnalystMap Algebra tool. Ultimately, flood depth maps and flood hazard maps for Q100, Q500 and Q1000 scenarios were prepared for the most down-stream area of the Mert River in Samsun, Turkey to assist local government agencies in the implementation of strategic planning that would minimize the effects of flooding and facilitate a coordinated response to flooding events.

Table 6. Debris factor selection based on flood depth, velocity and land use (Defra, 2006).

\begin{tabular}{lccc}
\hline Depths $(d)$ & Pasture/Arable & Woodland & Urban \\
\hline $0.00-0.25 \mathrm{~m}$ & 0 & 0 & 0 \\
$0.25-0.75 \mathrm{~m}$ & 0 & 0.5 & 1 \\
$d>0.75 \mathrm{~m}$ and/or $v>2 \mathrm{~m} / \mathrm{s}$ & 0.5 & 1 & 1 \\
\hline
\end{tabular}

Table 7. The four levels of flood hazard (Defra, 2006).

\begin{tabular}{|c|c|c|}
\hline $\begin{array}{l}\text { Thresholds for flood } \\
\text { hazard rating } \\
H=d(v+0.5)+D F\end{array}$ & $\begin{array}{l}\text { Degree of flood } \\
\text { hazard }\end{array}$ & Description \\
\hline$<0.75$ & Low & $\begin{array}{l}\text { Caution - "Flood zone with shallow, flowing water or } \\
\text { deep, standing water" }\end{array}$ \\
\hline $0.75-1.25$ & Moderate & $\begin{array}{l}\text { Dangerous for some (e.g. children) - "Danger: Flood } \\
\text { zone with deep or fast flowing water" }\end{array}$ \\
\hline $1.25-2.0$ & Significant & $\begin{array}{l}\text { Dangerous for most people - "Danger: Flood zone with } \\
\text { fast flowing water" }\end{array}$ \\
\hline$>2.0$ & Extreme & $\begin{array}{l}\text { Dangerous for all - "Extreme danger: Flood zone with } \\
\text { deep, fast flowing water" }\end{array}$ \\
\hline
\end{tabular}




\section{Results and discussion}

\subsection{MIKE 11 modeling}

In One Dimensional (1D) modeling in the current study, Q100, Q500 and Q1000 hydrographs were used for hydrodynamic simulation and in the investigation of the cross-sections of bridges. In the Q100, Q500 or Q1000 Mert River flow scenarios produced by 1D modeling, the discharge spread through the urbanized area in the downstream section of the river. For the Q100 scenario, the first six bridges $(\mathrm{C} 1-\mathrm{C} 6)$ in the most downstream section (closest to the sea) impeded flood water discharge and hence affected the water profile (Fig. 7). Furthermore, 1D modeling indicated that, even for the Q100 scenario, the river cannot cope with the volume of discharge required and it spills over the river banks. $2 \mathrm{D}$ modeling tends to be more realistic because it includes the whole river course and covers the entire inundation area, including the area from which the flood originates. It also showed that the first six bridge cross-sections would be unable to cope with the Q500 and Q1000 discharge scenarios.

The calculation area for the 1D model was limited to the river cross-sections. For that reason, it stacked water in the form of a column that exceeded the crosssectional area. This means that the model fails when the flood cannot pass a defined river section or sections. For this reason, 1D model users avoid this problem by keeping the river cross-sections wide enough to include the flood prone land adjacent to the river. However, in such cases, $2 \mathrm{D}$ or $1 \mathrm{D} / 2 \mathrm{D}$ coupled models should be used in flood modeling scenarios. In this study, the only aim of the $1 \mathrm{D}$ modeling was to demonstrate the inadequacy of the downstream river cross-sections to cope with Q100, Q500 and Q1000 peak discharge volumes, especially where the bridges are located.

\subsection{MIKE FLOOD modeling}

MIKE 11 and MIKE 21 FM models are combined in MIKE FLOOD environment with lateral links. Thus, when the MIKE 11 modeled the river, MIKE 21

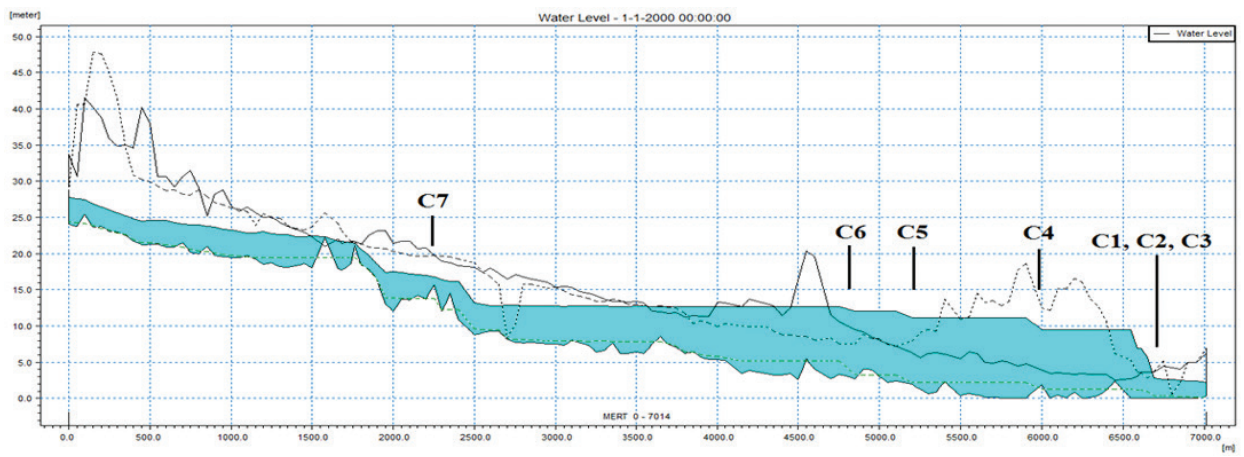

Figure 7. Mert River profile through the Q100 discharge. 
FM modeled the flood plain at the same time, with the aid of lateral links in MIKE FLOOD environment. Simulating the whole terrain with the 1D model will produce insufficient results. Besides, using a 2D model across the terrain will require huge amount of data and loss of time because of the modelling time. The use of the 1D/2D coupled model eliminates these two problems. Boundary conditions are flood hydrographs calculated for different return period peak discharges and simulation time is selected by MIKE environment based on hydrographs. The time intervals used for MIKE 11 and MIKE 21 simulations can be considered independently. MIKE FLOOD uses the time range and period of the MIKE 21 model while it is running. In this study 10 seconds were selected as the time interval in all models.

According to the modeling the maximum water depths for the Q100, Q500 and Q1000 scenarios are shown in Fig. 8. The figure shows that the study area is particularly threatened by floods.

Velocity maps, which are produced for the later development of flood risk maps, were obtained with 2D modeling; velocity results were obtained for Q100, Q500 and Q1000 scenarios. A magnified section of a velocity map, which includes the velocity vectors for the Q500 scenario, is shown in Fig. 9. In the area where bridge $\mathrm{C} 6$ is located, the velocity vectors are being compressed where the current is accelerating.
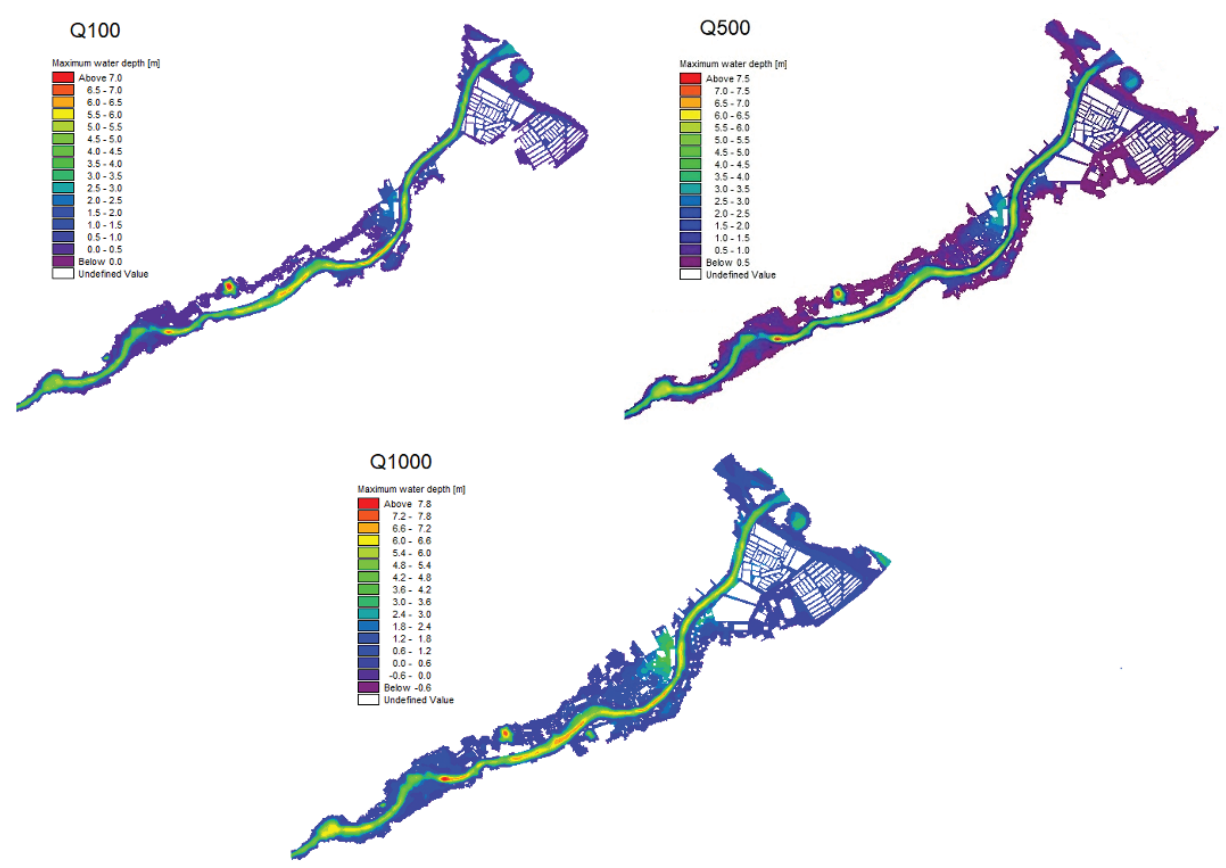

Figure 8. 2D water depth estimations for Q100, Q500, and Q1000 return period peak flood discharges for the Mert River, Turkey. 


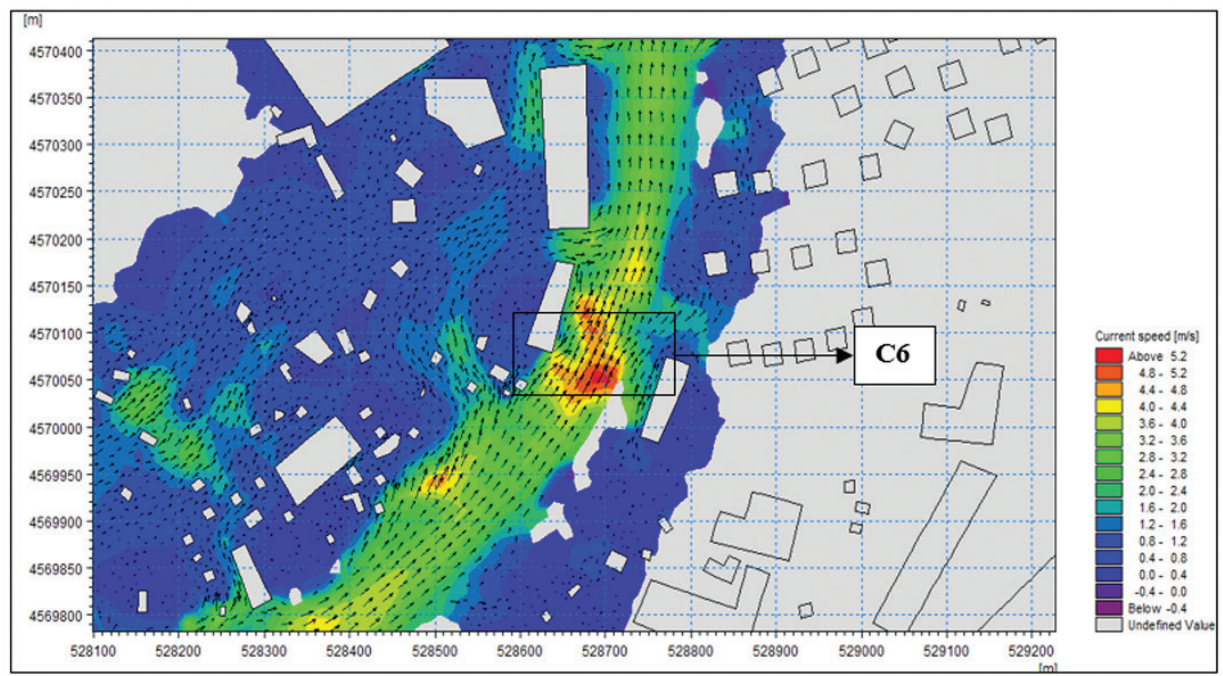

Figure 9. A section of the 2D modeling results for maximum velocity of the estimated Q500 discharge.

\subsection{Flood maps}

In this study, 'flood maps', namely flood extent, water depth and hazard maps, were generated with 2D modeling. For that purpose, by running the MIKE FLOOD model, the flood extent areas, water depth and flow velocity grid data

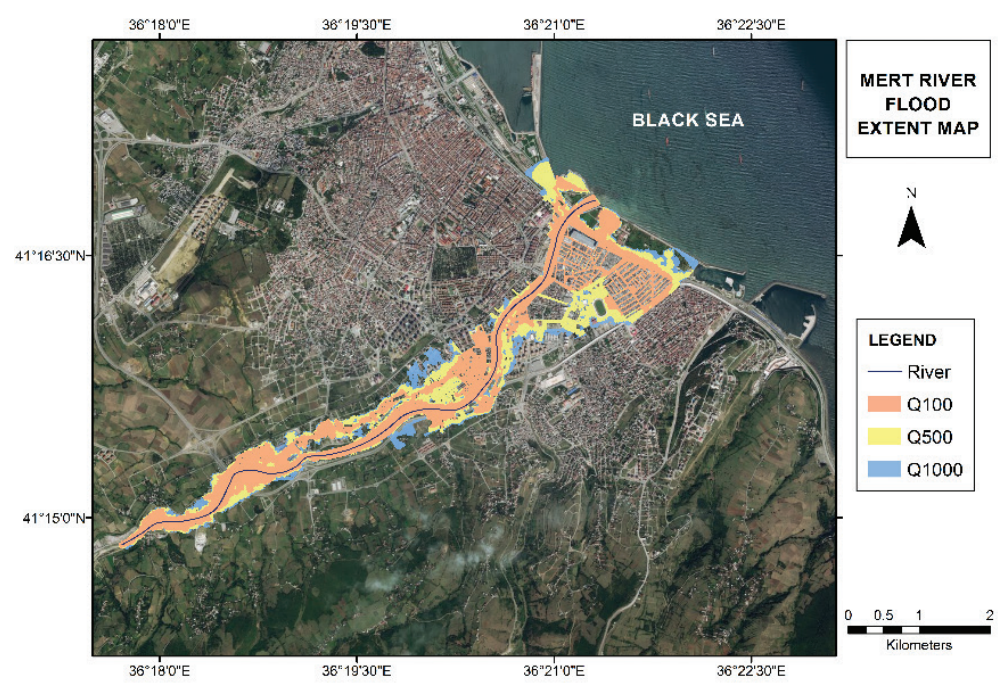

Figure 10. Flooding extent map for the Mert River for Q100, Q500, and Q1000 scenarios. 
necessary for hazard rating calculations were obtained. The projected maximum water depths for Q100, Q500 and Q1000 scenarios are shown in Figure 8; also, a section of the velocity results for Q500 modeling is shown in Fig. 9. The data bank of the Environmental Systems Research Institute (ESRI) of Turkey was accessed to obtain up-to-date base maps and ArcGIS 10.1 software was used to prepare the flood maps. Figure 10 shows the variations in the extents of inundation for the Q100, Q500 and Q1000 scenarios, and Figs. 11-13 show the detailed,

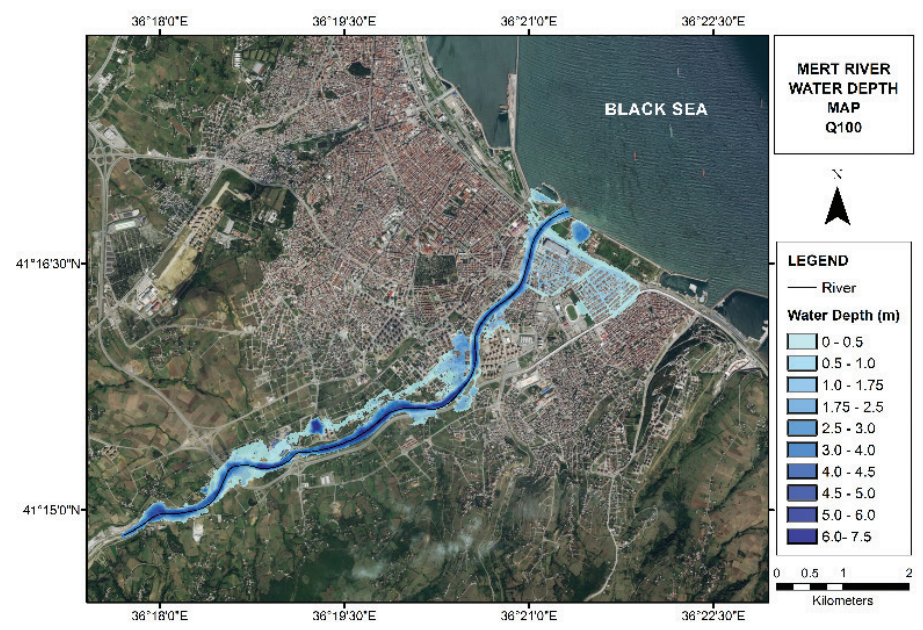

Figure 11. Water depth thematic map for a Mert River Q100 discharge.

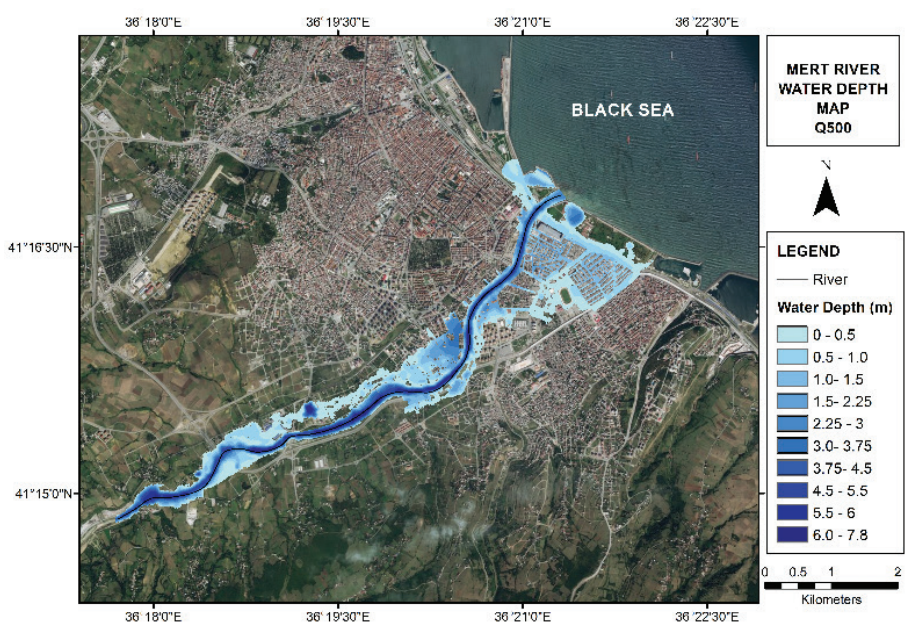

Figure 12. Water depth thematic map for a Mert River Q500 discharge. 


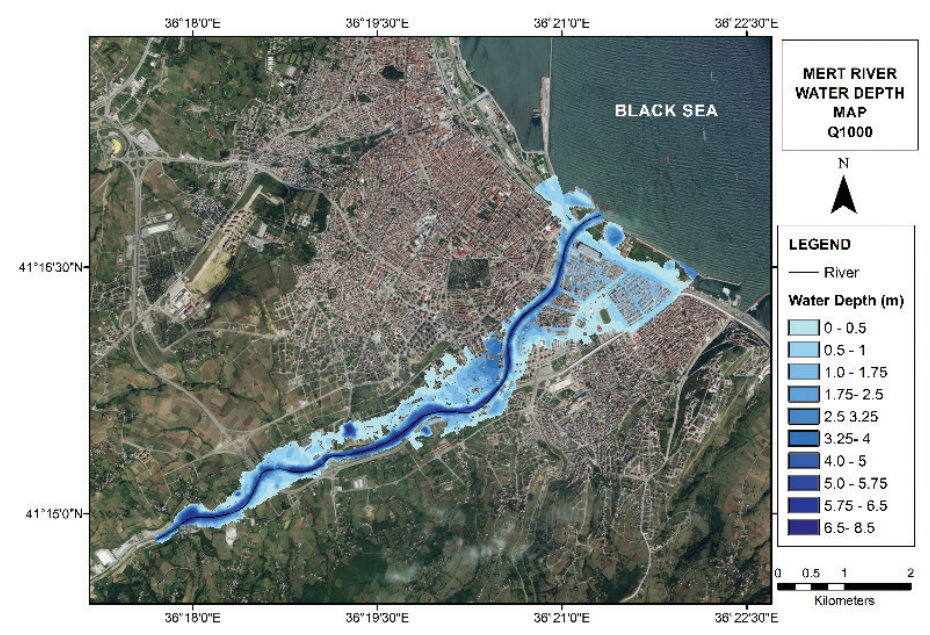

Figure 13. Water depth thematic map for a Mert River Q1000 discharge.

color-coded, thematic maps for water depth. In the maps, the various water depths are detailed through the use of a blue tone color scale.

The total areas of the industrial and residential areas on the Mert River flood plains are shown in Tab. 8. In the event of a Q100 flood, an estimated total area of 184 ha (66\% industrial and $34 \%$ residential) would be inundated. The industrial area includes a large shopping center, a stadium, social facilities and a main road network. Therefore, even for a Q100 level flood, the economic and social costs would be quite high. The consequences of a Q500 flood would obviously be more serious; a total area of 262 ha (61\% industrial and 39\% residential) would be inundated. In a Q1000 flood event, an estimated total area of 304 ha (59\% industrial and 41\% residential) would be inundated.

More realistic maps of flood hazard areas can be produced by using the "Hazard Rating" index (Defra, 2006). In the modeling in this study, the high flow hydrographs for Q100, Q500 and Q1000 return periods were use. For the hazard rate calculations, the required information was obtained from modeling results

Table 8. Flood plain areas (ha).

\begin{tabular}{lccc}
\hline \multicolumn{4}{c}{ Model area 1,200 ha } \\
\hline Flood plain & Q100 & Q500 & Q1000 \\
\hline Residential areas & 63 & 102 & 123 \\
Industrial area & 121 & 160 & 181 \\
Total & 184 & 262 & 304 \\
\hline
\end{tabular}


and subjected to Eq. (8), and flood hazard areas were defined. Figures 14-16 show the flood hazard thematic maps generated for the Mert River in this study.

The flood hazard maps show the projected flooded areas for each flood scenario, with the flooded areas subdivided into their specific hazard categories. The estimated total inundated area for the Q100 flood discharge is 184 ha (Tab. 9). The flood hazard rating for 81 ha (44.0\%) of that area is in the extreme category and applies mostly to areas near the river channel (Fig. 14). For the Q500 flood discharge, the total inundated area would be 262 ha (Tab. 9), with the flood hazard for 105 ha (40.1\%) in the extreme category. High flood hazard applies to the river channel and in the areas near the river banks where the terrain is lower (Fig. 15). For the expected Q1000 flood discharge, the total inundated area would be 304 ha (Tab. 9), with the flood hazard for 128 ha (42.1\%) in the extreme category (Fig. 16).

Table 9. Flood hazard categories for Q100, Q500 and Q1000 scenarios for the Mert River, Turkey.

\begin{tabular}{lccc}
\hline \multicolumn{4}{c}{ Model Area 1,200 ha } \\
\hline Hazard category & Q100 area (ha) & Q500 area (ha) & Q1000 area (ha) \\
\hline Low & 77 & 94 & 99 \\
Moderate & 15 & 37 & 41 \\
Significant & 11 & 26 & 36 \\
Extreme & 81 & 105 & 128 \\
Total & 184 & 262 & 304 \\
\hline
\end{tabular}

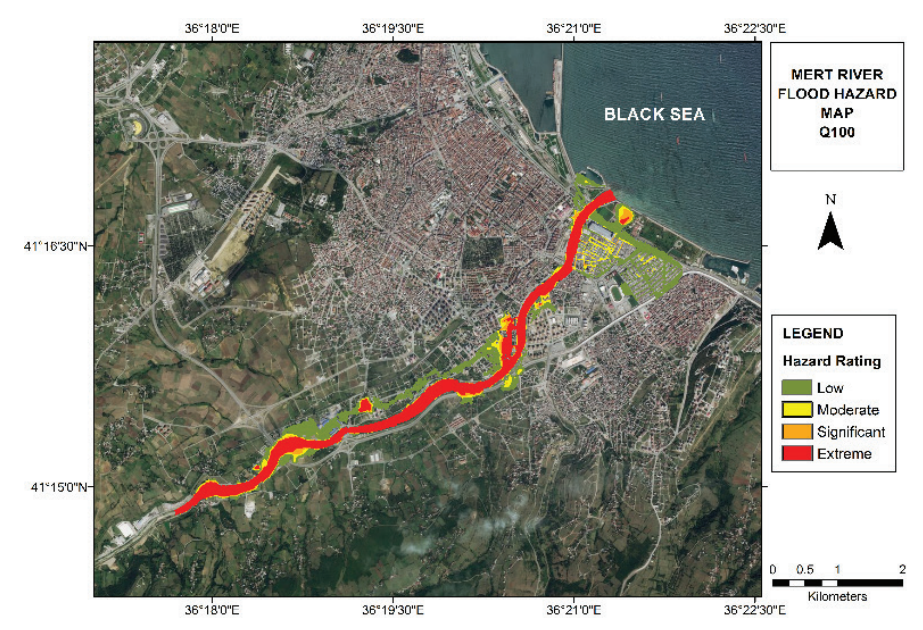

Figure 14. Flood hazard thematic map for the Mert River for a Q100 discharge. 


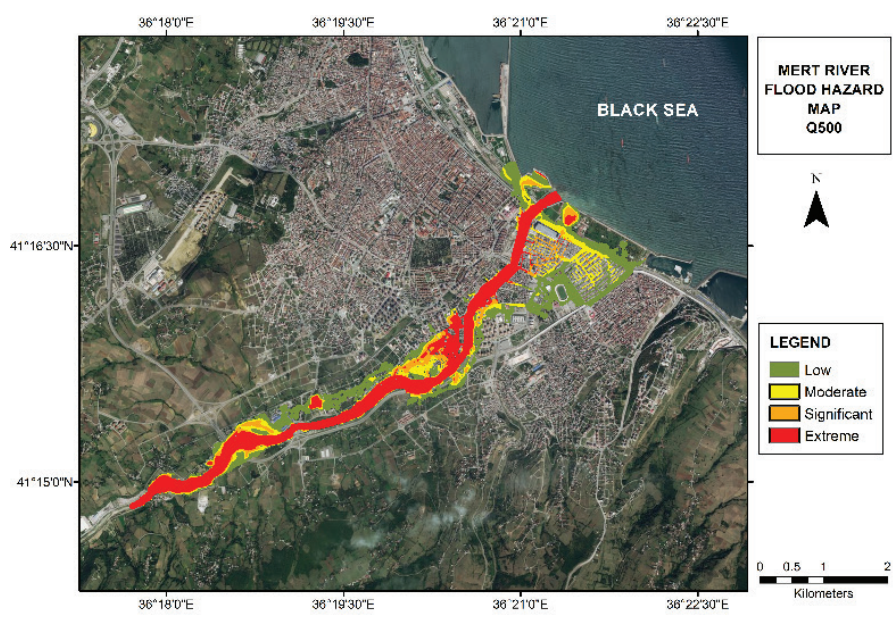

Figure 15. Flood hazard thematic map for the Mert River for a Q500 discharge.

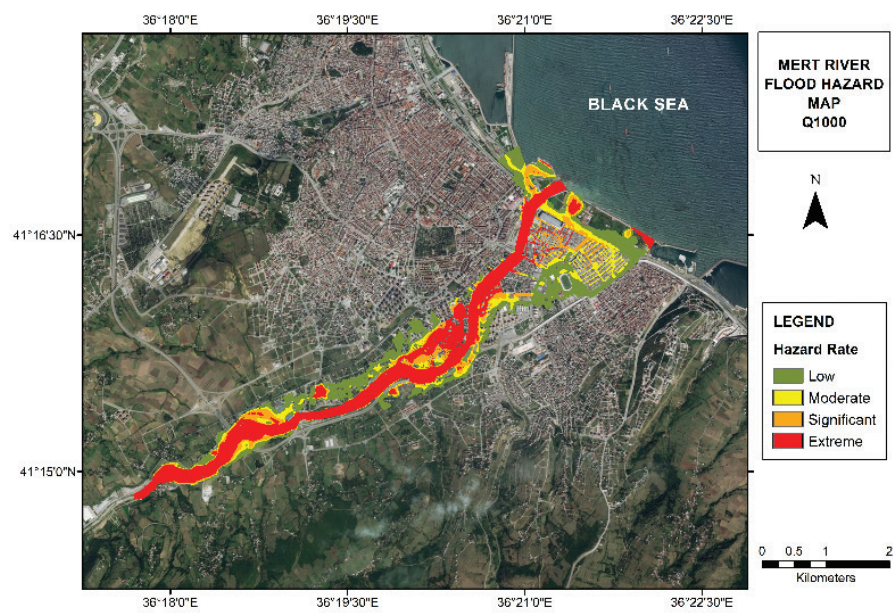

Figure 16. Flood hazard thematic map for the Mert River for a Q1000 discharge.

\section{Conclusions}

Flood events, which frequently affect cities, agricultural land, and infrastructure such as roads, dams and bridges, impose social and financial costs, and in some cases, cause the loss of lives of people and animals. Having advanced knowledge of flood prone areas and estimates of the effects of floods for different return periods provides an opportunity to implement plans that minimize loss of life and injuries, social disruption and damage to public and private assets. Changes in land use, including increased unplanned construction along river courses, 
along with their constriction, increases the maximum flood discharge rate and hence the water depth and surface area of the flooded area. In this study, the Mert River, which is located in Samsun Province in the Black Sea region of northern Turkey, was modeled with MIKE powered by DHI software. MIKE 11, MIKE 21 and MIKE FLOOD models were used for the numerical analysis of different flood periods that ranging from 5 to 1,000 years.

1D modeling demonstrated that the river cross-sections are inadequate to cope with peak flood flows, especially where the bridges are located. The effects on the flood profile of the four bridges closest to the sea are much more severe than the effects of the other three bridges further upstream. The engineering structures in and on the river will cause water to overflow the river banks and cause flooding, as seen in the 2012 flood event. For this reason, the statuses of the existing bridges should be carefully evaluated by the local authorities and remedial action taken where necessary.

In addition, in this study, flood maps were produced with $2 \mathrm{D}$ modeling. The modeling showed that the most downstream section of the Mert River, where the industrial area is located, is at high risk, as seen in the flood extent, water depth and hazard maps. The results of this study can be employed by the local authorities and regional government in Samsun to assist planning, coordination and management operations that reduce the social and economic costs of future floods. In addition, its value to the community could be increased by adding risk management and damage assessments.

Acknowledgement - The authors thank Danish Hydraulic Institute for providing the full academic version of MIKE software and the Turkish General Directorate of State Hydraulic Works Samsun Office for providing the hydrological data. Also specially thank Dr. Gregory T. Sullivan for proofreading and comments on an earlier version of this manuscript. study.

Conflict of interest statement - The authors have no conflicts of interest in relation to this

\section{References}

Ahmed, F. (2010): A hydrodynamic model for the Lower Rideau River, Nat. Hazards, 55, 85-94, https://doi.org/10.1007/s11069-010-9559-9.

Alho, P. and Aaltonen, J. (2008): Comparing 1D hydraulic model with a 2D hydraulic model for the simulation of extreme glacial outburst floods, Hydrol. Process., 22, 1537-1547, https:/doi. org/10.1002/hyp.6692.

Bates, P. D. and De Roo, A. (2000): A simple raster-based model for flood inundation simulation, J. Hydrol., 236, 54-77, https://doi.org/10.1016/S0022-1694(00)00278-X.

Bellos, V. and Tsakiris, G. (2015): Comparing various methods of building representation for 2D flood modelling in built-up areas water, Resour. Manage., 29, 379-397, https://doi.org/10.1007/s11269014-0702-3.

Carrivick, J. L. (2006): Application of 2D hydrodynamic modelling to high-magnitude outburst floods: An example from Kverkfjöll, Iceland, J. Hydrol., 321, 187-199, https://doi.org/10.1016/j. jhydrol.2005.07.042. 
Cesur, D. (2007): GIS as an information technology framework for water modeling, J. Hydroinform., 9, 123-134, https://doi.org/10.2166/hydro.2007.008.

Chaudhry, M. H. (2008): Open-channel flow. Springer, Boston, 523 pp.

Chow, V. T. (1959): Open channel hydraulics. McGraw-Hill, New York, 700 pp.

Cook, A. and Merwade, V. (2009): Effect of topographic data, geometric configuration and modeling approach on flood inundation mapping, J. Hydrol., 377, 131-142, https://doi.org/10.1016/j. jhydrol.2009.08.015.

Courant, R., Friedrichs, K. and Lewy, H. (1928): Uber die partiellen differenzengleichungen der mathematischen physic, Mathematische Annalen, 100, 32-74 (in German).

Cowan, W. L. (1956): Estimating hydraulic roughness coefficients, Agricultural Engineering, 37, 473-475.

De Roo, A. P. J., Wesseling, C. G. and Van Deursen, W. P. A. (2000): Physically based river basin modelling within a GIS: The LISFLOOD model, Hydrol. Process., 14, 1981-1992, https://doi. org/10.1002/1099-1085(20000815/30)14:11/12<1981::AID-HYP49>3.0.CO;2-F.

Defra (Department for Environment, Food and Rural Affairs) (2006): Flood risks to people, last accessed on 1 September 2018 at http://randd.defra.gov.uk/Document.aspx?Document=FD2321_3437_ TRP.pdf

DHI (Danish Hydraulic Institute) (2016a): MIKE 11 A modelling system for rivers and channels, Reference Manual. Denmark.

DHI (Danish Hydraulic Institute) (2016b): MIKE 21 Flow model FM, hydrodynamic module, Reference Manual. Denmark.

DHI (Danish Hydraulic Institute) (2016c): MIKE FLOOD, Reference Manual. Denmark.

DSI (General Directorate of State Hydraulic Works) (2013): Preliminary investigation report on the flood protection of Mert and Kurtun river basins. Samsun: XII ${ }^{\text {th }}$ Regional Directorate of State Hydraulic Works (in Turkish).

Gul, G. O., Harmancioglu, N. and Gul, A. (2010): A combined hydrologic and hydraulic modeling approach for testing efficiency of structural flood control measures, Nat. Hazards, 54, 245-260, https:// doi.org/10.1007/s11069-009-9464-2.

Haltas, I., Elci, S. and Tayfur, G. (2016): Numerical simulation of flood wave propagation in two-dimensions in densely populated urban areas due to dam break, Water Resour. Manage., 30, 56995721, https://doi.org/10.1007/s11269-016-1344-4.

Hooijer, A., Klijn, F., Pedroli, G. B. M. and Van Os, A. G. (2004): Towards sustainable flood risk management in the Rhine and Meuse river basins: Synopsis of the findings of IRMA-SPONGE, River Res. App., 20, 343-357, https://doi.org/10.1002/rra.781.

Horritt, M. S. and Bates, P. D. (2001): Predicting floodplain inundation: Raster-based modelling versus the finite-element approach, Hydrol. Process., 15, 825-842, https://doi.org/10.1002/hyp.188.

Horritt, M. S. and Bates, P. D. (2002): Evaluation of 1D and 2D numerical models for predicting river flood inundation, J. Hydrol., 268, 87-99, https://doi.org/10.1016/S0022-1694(02)00121-X.

Huthoff, F., Remo, J. W. F. and Pinter, N. (2015): Improving flood preparedness using hydrodynamic levee-breach and inundation modelling: Middle Mississippi River, USA, J. Flood Risk Manag., 8, 2-18, https://doi.org/10.1111/jfr3.12066.

Komi, K., Jeffery, N., Trigg, M. A. and Diekkruger, B. (2017): Modelling of flood hazards extent in data spares areas: A case study of the Oti River Basin, West Africa, J. Hydrol. Reg. Stud., 10, 122-132, https://doi.org/10.1016/j.ejrh.2017.03.001.

Leedal, D., Neal, J., Beven, K., Young, P. and Bates, P. (2010): Visualization approaches for communicating real-time flood forecasting level and inundation information, J. Flood Risk Manag., 3, 140-150, https://doi.org/10.1111/j.1753-318X.2010.01063.x.

Maidment, D. and Djokic, D. (2000): Hydrologic and hydraulic modeling support with geographic information systems. Environmental Systems Research Institute, America.

Masood, M. and Takeuchi, K. (2012): Assessment of flood hazard, vulnerability and risk of mideastern Dhaka using DEM and 1D hydrodynamic model, Nat. Hazards, 61, 757-770, https://doi. org/10.1007/s11069-011-0060-x. 
Merz, B., Thieken, A. H. and Gocht, M. (2007): Flood risk mapping at the local scale: Concepts and challenges, in: Flood risk management in Europe, edited by Beguim, S., Stive, M. and Hall, J. W., Springer, https://doi.org/10.1007/978-1-4020-4200-3_13.

MGM (Turkish State Meteorological Service) (2018): Long-term all parameters bulletin for the Samsun Station. Ankara, Turkey.

Mignot, E., Paquier, A. and Haider, S. (2006): Modeling floods in a dense urban area using 2D shallow water equations, J. Hydrol., 327, 186-199, https://doi.org/10.1016/j.jhydrol.2005.11.026.

Mockus, V. (1965): National engineering handbook hydrology chapters (NRCS), Chapter 21. Natural Resources Conservation Service, USA, $127 \mathrm{pp}$.

Ozdemir, H. (1978): Applied flood hydrology. General Directorate of State Hydraulic Works Ankara, Turkey. (in Turkish)

Pearson, C. and Davies, T. (1997): Stochastic methods, in: Floods and droughts: The New Zealand experience, edited by Mosley, M. P. and Pearson, M. P. WIT Press, pp 65-87.

Petrow, T., Thieken, A. H., Kreibich, H., Bahlburg, C. H. and Merz, B. (2002): Improvements on flood alleviation in Germany: Lessons learned from the Elbe flood in August, Environ. Manage., 38, 717-732, https://doi.org/10.1007/s00267-005-6291-4.

Quiroga, V. M., Kure, S., Udo, K. and Mano, A. (2016): Application of 2D numerical simulation for the analysis of the February 2014 Bolivian Amazonia flood: Application of the new HEC-RAS version 5, RIBAGUA - Revista Iberoamericana del Agua, 3, 25-33, https://doi.org/10.1016/j.riba.2015.12.001.

ShahiriParsa, A., Noori, M., Heydari, M. and Rashidi, M. (2016): Floodplain zoning simulation by using HEC-RAS and CCHE2D models in the Sungai Maka River, Air Soil Water Res., 9, 55-62, https://doi.org/10.4137/ASWR.S36089.

Timbadiya, P., Patel, P. and Porey, P. (2014): A 1D-2D coupled hydrodynamic model for river flood prediction in a coastal urban floodplain, J. Hydrol. Eng., 20(2), https://doi.org/10.1061/(ASCE) HE.1943-5584.0001029.

Vojtek, M. and Vojteková, J. (2016): Flood hazard and flood risk assessment at the local spatial scale: A case study, Geomat. Nat. Haz. Risk, 7, 1973-1992, http://dx.doi.org/10.1080/19475705.2016.116 6874.

Vozinaki, A. E. K., Morianou, G. G., Alexakis, D. D. and Tsanis, I. K. (2017): Comparing 1D and combined 1D/2D hydraulic simulations using high-resolution topographic data: A case study of the Koiliaris basin, Greece, Hydrolog. Sci. J., 62, 642-656, https://doi.org/10.1080/02626667.2016.125 5746.

Willems, P., Arnbjerg-Nielsen, K., Olsson, J. and Nguyen, V. T. V. (2012): Climate change impact assessment on urban rainfall extremes and urban drainage: Methods and shortcomings, Atmos. Res., 103, 106-118, https://doi.org/10.1016/j.atmosres.2011.04.003.

Yalcin. E. (2019): Two-dimensional hydrodynamic modelling for urban flood risk assessment using unmanned aerial vehicle imagery: A case study of Kirsehir, Turkey, J. Flood Risk Manag., 12 (Suppl. 1), https://doi.org/10.1111/jfr3.12499.

Zerger, A. and Wealands, S. (2004): Beyond modelling: linking models with GIS for flood risk management, Nat. Hazards, 33, 191-208, https://doi.org/10.1023/B:NHAZ.0000037040.72866.92.

SAŽETAK

\title{
Procjena opasnosti od poplave na intenzivno urbaniziranom području podložnom poplavama - Studija slučaja iz provincije Samsun, Turska
}

\author{
Neslihan Beden i Aslı Ülke Keskin
}

Poplava je jedan od najkatastrofalnijih događaja među širokim spektrom prirodnih katastrofa koje utječu na ljudske zajednice. Identifikacija poplavno podložnih područja i 
vjerojatnost nastanka poplava ili procjena razdoblja povratka od suštinskog su značaja za pravilno planiranje upravljanja poplavama i minimiziranje socijalnih i ekonomskih troškova štete od poplave. U ovoj studiji razvijeni su 1D/2D modeli poplava rijeke Mert, koja se uliva u Crno more kod Samsuna na sjeveru središnje Turske. Na temelju rezultata modeliranja poplava, izrađeni su obim poplava, dubina poplave i opasnosti od poplave za rijeku te su pokazali da je proučavano područje posebno podložno poplavi, o čemu svjedoče katastrofalne poplave u 2012. Točnije, procijenjeni 100-, 500- i 1000-godišnji vršni ispusti utjecali bi na 184 ha, 262 ha i 304 ha na studijskoj površini od 1200 ha. Ocjene opasnosti za područja na koja se očekuje da će biti pogođene prikazane su u generiranim kartama opasnosti od poplave. Rezultate ovog istraživanja mogu koristiti lokalne samouprave u Samsunu za razvoj politika, strategija i radnji koje će pomoći umanjivanju socijalnih i ekonomskih učinaka poplava, posebno susjednih dijelova nizvodno gdje je intenzivni razvoj na poplavnoj površini.

Ključne riječi: modeliranje poplava, mapiranje poplava, MIKE FLOOD, Samsun, Turska

Corresponding author's address: Neslihan Beden, Construction Department, Kavak Vocational School, Samsun University, Samsun, Turkey; tel: +90 3623130221 (interior: 3014), fax: +90 36274135 82; ORCID: 00000002-5573-8016; e-mail: neslihan.beden@samsun.edu.tr 